\title{
Insights on the Origin of Vitrified Rocks from Serravuda, Acri (Italy): Rock Fulgurite or Anthropogenic Activity?
}

\author{
Chiara Elmi ${ }^{1, * \mathbb{C}}$, Anna Cipriani ${ }^{2}$, Federico Lugli $^{3}$ and Giampaolo Sighinolfi ${ }^{2}$ \\ 1 Department of Geology and Environmental Sciences, James Madison University, \\ Harrisonburg, VA 22807, USA \\ 2 Dipartimento di Scienze Chimiche e Geologiche, Università di Modena e Reggio Emilia, 41125 Modena, Italy; \\ anna.cipriani@unimore.it (A.C.); sighinolfig@yahoo.it (G.S.) \\ 3 Dipartimento di Beni Culturali, Università di Bologna, 40126 Bologna, Italy; federico.lugli6@unibo.it \\ * Correspondence: elmicx@jmu.edu
}

Citation: Elmi, C.; Cipriani, A.; Lugli, F.; Sighinolfi, G. Insights on the Origin of Vitrified Rocks from Serravuda, Acri (Italy): Rock Fulgurite or Anthropogenic Activity? Geosciences 2021, 11, 493. https:// doi.org/10.3390/geosciences11120493

Academic Editors: Matteo Alvaro and Jesus Martinez-Frias

Received: 1 November 2021

Accepted: 27 November 2021

Published: 1 December 2021

Publisher's Note: MDPI stays neutral with regard to jurisdictional claims in published maps and institutional affiliations.

Copyright: (c) 2021 by the authors. Licensee MDPI, Basel, Switzerland. This article is an open access article distributed under the terms and conditions of the Creative Commons Attribution (CC BY) license (https:/ / creativecommons.org/licenses/by/ $4.0 /)$.

\begin{abstract}
In this study, twenty five partially vitrified rocks and four samples of vitrified rocks collected on the top hill called Serravuda (Acri, Calabria, Italy) are analyzed. The goal is to shed light on the origin of these enigmatic vitrified materials. The analyzed vitrified rocks are a breccia of cemented rock fragments (gneiss, granitoid, and amphibolite fragments) which extends for more than $10 \mathrm{~m}$, forming a continuous mass along the northern and north-west border of the flat top hill. Surrounded by the vitrified accumulation, exposed Paleozoic granitoid substrate rocks show limited melting or heat-alteration processes. By mapping minerals embedded in the glass matrix via X-ray powder diffraction (XRPD) and scanning electron microscopy (SEM), an interpretation of source rock material, reactions, and thermometric indications to form vitrified materials on the top hill of Serravuda, Acri (Italy), is provided. The mineralogical composition of heated or partially vitrified samples is heterogeneous owing to the effects of heating events, but it mostly recalls the parent rock composition (gneiss, granitoid, and amphibolite). The presence of quartz, cristobalite, tridymite, mullite, plagioclase, hercynite, cordierite, and olivine in Serravuda partially vitrified rocks and glasses suggests that samples were subjected to pyrometamorphism and the temperature range at which the glass formed was about $1000-1100{ }^{\circ} \mathrm{C}$ in the presence of hydrous gas, burning organic material (e.g., wood), and assuming thermodynamic equilibrium. Lithologies of the heated or partially vitrified rock fragments are a mixture of parent rocks not outcropping on the top of the hill such as gneiss and amphibolite. Data suggest that Serravuda vitrified rocks are most likely the result of anthropic activities and could represent remnants of vitrified fort walls. The mineral assemblage of partially vitrified rocks and glasses suggests that the fort walls were made of slabs derived from the local metamorphic rocks with the addition of Serravuda substrate Paleozoic granitoid rocks to improve the strength and insulation of the fort walls.
\end{abstract}

Keywords: vitrified rocks; X-ray diffraction; mineral reactivity; Serravuda

\section{Introduction}

In 1971, a crust of melted rocks of 50-90 cm thick was found on the top of a hill called Serravuda at about $3 \mathrm{~km}$ North-West of Acri (Calabria, Italy, 39 $30^{\prime} 37^{\prime \prime} \mathrm{N} ; 1^{\circ} 22^{\prime} 06^{\prime \prime} \mathrm{E}$ ) by Francesco Foggia. The area is part of the Sila Plateau (Paleozoic granitoids), where Kinzigitic Formation (high-grade metamorphic rocks, gneiss) dominates.

A preliminary investigation on the vitrified rocks from Serravuda was reported by Bertolani [1]. The author [1] suggested that the extensive melting of refractory material occurred under very high temperature conditions and the event caused extensive melting of parent rocks and intensive macro and micro fracturing and pervasive planar deformation features (PDF) in quartz. Bertolani's [1] investigation via a petrographic microscope led to the uncertain interpretation that the origin is meteor impact, lightning strike, or anthropogenic rituals (prehistoric or protohistoric). 
The present study aims to shed light on the physical-chemical effects occurring in rocks in response to environmental or anthropological changes. The mineralogical and chemical features of residual minerals in the glass were studied to assess the conditions at which the vitrified rocks were formed and in turn to explain their genesis.

\section{Materials and Methods}

\subsection{Geologic Setting of the Outcrop of Fused Rocks at Serravuda Hill}

The vitrified samples, along with the samples of substrate rock materials, were collected on the top of a hill called Serravuda (926 m a.s.l.) in the southern Apennines near Acri, Italy $\left(39^{\circ} 30^{\prime} 11^{\prime \prime} \mathrm{N} ; 16^{\circ} 22^{\prime} 06^{\prime \prime} \mathrm{E}\right)$ in Spring 2018 and Summer 2019. Details on the sampling areas and macroscopic features and lithology of samples are reported in Table 1.

Table 1. Location, macroscopic features, and attributed lithology of the analyzed samples.

\begin{tabular}{|c|c|c|c|}
\hline Sample & Locality & Lithology & Description \\
\hline \multicolumn{4}{|r|}{ Substrate Basement Rocks } \\
\hline SE 3 & $\begin{array}{l}\text { top of an elevation } 50 \mathrm{~m} \mathrm{~N} \text {-E from } \\
\text { the Serravuda hill }\end{array}$ & granitoid & Reddish fine-grained weathered granitoid \\
\hline SE 5 & top of Serravuda hill & granitoid & Light-gray coarse-grained granitoid, partially weathered \\
\hline SE 8 & top of the Serravuda hill & granitoid & Light gray medium-grained granitoid, with whitish hydrothermal veins (calcite?) \\
\hline SE 10 & top of Serravuda hill & granitoid & Light-gray coarse-grained, partially weathered granitoid \\
\hline \multicolumn{4}{|c|}{ Heated or Partially Vitrified Rock Fragments } \\
\hline SV $3 \mathrm{~A}$ & Sample from cemented block $\mathrm{C}$ & gneiss & Medium-sized $(10 \mathrm{~cm})$ reddish, coarse-grained mica rich-gneiss pebble with minor fracturing. \\
\hline SV 4C & Sample from cemented block C & granitoid & $\begin{array}{l}\text { SV4-C is a coarse-grained strongly brecciated rock fragment (quartz-rich foliated granitoid) } \\
\text { with thin black veins (glass) localized in the fracture plains. }\end{array}$ \\
\hline SV 5 & Sample from cemented block $\mathrm{C}$ & amphibolite & $\begin{array}{l}\text { SV5 is a large }(>15 \mathrm{~cm}) \text { dark-grey, strongly fractured rock pebble apparently unaffected } \\
\text { by melting. }\end{array}$ \\
\hline SV 6 & $\begin{array}{l}\text { Large }(>15 \mathrm{~cm}) \text { fragment from } \\
\text { cemented block } C\end{array}$ & amphibolite & Light-gray coarse-grained strongly fractured pebble with reddish coating. \\
\hline SE 2 & top of Serravuda hill & granitoid & $\begin{array}{l}\text { Loose large pebble }(>20 \mathrm{~cm}) \text { light-gray, quartz-rich rock showing intense fracturing and } \\
\text { pervasive veins of dark vitreous material. }\end{array}$ \\
\hline SE 6 & top of Serravuda hill & granitoid & $\begin{array}{l}\text { Loose medium-sized }(<15 \mathrm{~cm}) \text { light-gray feldspar-rich pegmatitic granitoid pebble, intensely } \\
\text { fractured but no evidence of melting }\end{array}$ \\
\hline SE 7 & top of Serravuda hill & gneiss & $\begin{array}{l}\text { Loose, medium-sized }(<15 \mathrm{~cm}) \text {, dark heavy foliated gneiss pebble, intensely fractured but with } \\
\text { no evidence of melting }\end{array}$ \\
\hline SE 9 & NE flank of the Serravuda hill & gneiss & Greenish/gray foliated rock rich in phyllosilicates (biotite-chlorite gneiss?). \\
\hline SE 11 & top of Serravuda hill & granitoid & $\begin{array}{l}\text { Loose, medium-sized }(10 \mathrm{~cm}) \text { reddish pebble of granitoid with minor fracturing and no } \\
\text { evidence of melting }\end{array}$ \\
\hline SE 12 & top of Serravuda hill & granitoid & Loose, medium-sized $(5-10 \mathrm{~cm})$ dark-grey pebble, intensively fractured \\
\hline SE 13 & top of Serravuda hill & quartzite & $\begin{array}{l}\text { Loose, medium-sized }(5-10 \mathrm{~cm}) \text { reddish, coarse-grained quartz-rich pebble, totally covered by } \\
\text { a fusion crust. }\end{array}$ \\
\hline SE 14 & NE flank of the Serravuda hill & gneiss & Dark-gray foliated phyllosilicate-rich rock (kinzigitic gneiss) \\
\hline SE 15 & NE flank of the Serravuda hill & gneiss & Dark-gray foliated phyllosilicate-rich rock (kinzigitic gneiss) \\
\hline SV13P & Sample from cemented block SV1 & granitoid & $\begin{array}{l}\text { SV1-3P is a medium sized }(5-10 \mathrm{~cm}) \text {, light-colored, coarse-grained quartz-rich granitoid, } \\
\text { intensely fractured pebble covered by a dark vitreous crust. }\end{array}$ \\
\hline \multicolumn{4}{|c|}{ Vitreous Cements from Block SV1 and C } \\
\hline SV 1-2 & Selected from cemented block SV1 & glass & $\begin{array}{l}\text { Black colored, slightly vesicular glass containing abundant relics of light-colored minerals } \\
\text { (plagioclase and quartz) or newly formed coarse-grained (pegmatitic) mineral phases. }\end{array}$ \\
\hline SV 1-3V & Sample from cemented block SV1. & glass & Dark vitreous matrix englobing sample SV1-3P. \\
\hline SV 1-4 & Sample from cemented block SV1 & glass & $\begin{array}{l}\text { Black, vesicular glass containing abundant relics of light-colored coarse-grained mineral } \\
\text { phases (plagioclase and quartz). }\end{array}$ \\
\hline SV 1-A & Sample from cemented block SV1. & glass & $\begin{array}{l}\text { Composite sample of dark, dense, not vesicular vitreous material accumulated in a large } \\
\text { pocket (up to } 15 \mathrm{~cm} \text { diameter) or deposited along void channels, containing abundant } \\
\text { light-colored crystals (plagioclase and quartz). }\end{array}$ \\
\hline SV 1-B & Sample from cemented block SV1. & glass & $\begin{array}{l}\text { Composite sample of dark, strongly vesicular vitreous material usually deposited as pockets } \\
\text { and incrustations in cavities within rock fragments. }\end{array}$ \\
\hline SV 4-V & Sample from cemented block $\mathrm{C}$ & glass & Dark, strongly vesicular vitreous material associated to and partially covering sample SV4-C. \\
\hline
\end{tabular}

The Serravuda area is characterized by a series of hills and reliefs characterized by rounded peaks lying mainly North-South. The northern edge of the top of Serravuda hill hosts the fused rocks and is characterized by a flattened top that is distinct from the top of neighboring reliefs. The dense vegetation along the slopes of the hills inhibits observation of the substrate lithology. The fused rock outcrop is elliptical in shape and measures $32 \mathrm{~m}$ $\mathrm{E}-\mathrm{W}$ and $25 \mathrm{~m} \mathrm{~N}-\mathrm{S}$. Folk tradition bequeaths that Serravuda hill is a volcano and a great fire broke out on Serravuda towards the end of the 17th century. However, no volcanism in the area was observed and the fire was attributed to a lightning strike or prehistoric or protohistoric rituals [1]. 
The vitrified rocks under study are a breccia of cemented rock fragments (gneiss, granitoid, and amphibolite fragments), which extends for more than $10 \mathrm{~m}$, forming a continuous mass along the northern and north-west border of the flat top surface. In the central part of the top flat surface surrounded by the vitrified rocks, exposed granitoid substrate rocks show limited melting or heat-transformation processes. Test digging in three places along the northern border revealed that fused mass thickness varies from 50 to $90 \mathrm{~cm}$. Underneath the fused mass, there is a layer of reddish rock fragments at a depth of $25-60 \mathrm{~cm}$. This oxidized layer lies on detrital material with a black-colored surface. At a depth of 1.40-1.50 m, the detrital cover sits on substrate rocks. No continuous fused rocks or in situ oxidized rock fragments were found on the southern side of Serravuda hill.

The substrate rocks that host the samples under study are part of the Sila Plateau $[2,3]$. The Sila Plateau originated from igneous granitoid plutons intruding during the Carboniferous and Permian subduction and were uplifted and metamorphosed by the creation of the Apennines and erosion [2,3]. The Sila Plateau consists of a variety of medium-high metamorphic rock sequences that includes kinzigitic gneiss, amphibolite, and granitoid bodies. Kinzigitic gneiss is the most common rock and contains quartz, garnet, sillimanite, and plagioclase albite [3]. Most of the medium-high metamorphic rocks underwent diffused and intense regional retro-metamorphism to greenschist facies.

During recent field expeditions in 2018 and 2019, field observations showed that substrate rocks exposed on the top of Serravuda Mount and adjacent reliefs consist of medium-large grained plagioclase-quartz-rich felsic rocks (granitoids).

\subsection{Sample Collection}

Three distinct rock sets were collected during two visits to the outcrop in 2018 (SV samples) and 2019 (SE samples).

(a) Substrate rocks outcropping on the top and on the flanks of the Serravuda hill. Field observations show that rocks outcropping on the top of the Serravuda hill consist of whitish-light colored minerals macroscopically identified as quartz and plagioclase. Substrate rocks show limited melting or heat-alteration processes. Sample SE 3 is a reddish weathered granitoid rock collected on the top of a neighboring hill. SE 5, SE 8, and SE 10 samples are medium-large grained granitoid rocks that were previously identified by Bertolani [1] as migmatites.

(b) Heated or partially vitrified rock fragments collected along the northern and northwest flanks of the flat top of the Serravuda hill. This rock set includes a variety of different materials (about $10 \mathrm{~cm}$ average size) present as loose fragments on the top of the Serravuda hill. Colorless or greenish vitreous material was observed as thin crust covering some pebbles. SV 4-C, SE 6, SE 11, SE 12, SV 1-3P samples are granitoid that were subjected to intense heating effects with mineral fracturing and partial fusion of the rock. SV 6, SE 9, SV 3-A, SV 4-C, SV 4-V, SV 5, SV 1-3P, SV 1-3V were extracted from two distinct cemented blocks labelled 1 (12 kg, Figure 1a) and C (25 kg, Figure 1b) collected at the NW flanks of the Serravuda hill. SV4C and SV1-3P represent mostly or poorly molted material from SV4 and SV1 fragments, SV 4-V is mainly glassy material present as a crust partially covering SV4 fragment. SE 9, SE 14, and SE 15 samples of dark-brown medium-high grade biotite rich-gneisses were collected along the N-W flanks of the Serravuda hill. The products of the fusion consist of reddish-black vitreous materials in veins veinlets inside the fragments and external crusts or pockets. Lithologies of the heated or partially vitrified rock fragments are mixed from parent rocks not outcropping on the top of the hill such as hypersilicic rocks (quartzite, SE 13), mica-rich gneisses (SV 3-A, SE 7, SE 9, SE 14, SE 15) and amphibolite (SV 5, SV 6).

(c) Dark-vitreous materials present as large veins or pockets (5-10 cm average size) cementing SV 1 and C rock fragments. Samples in this set were extracted (separated) from SV 1 and $C$ where they are present as veins and pockets. Samples labelled SV 1-3V and SV 4-V are glassy crusts covering SV 1 and SV 4 loose rock fragments. 
Sample SV 1-A is a massive black-glass with few vesicles. SV 1-B is a vesicular glass rich with crystalline inclusions.

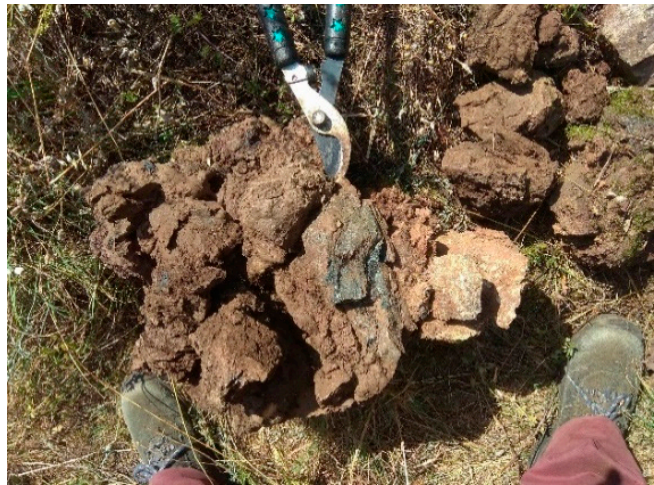

(a)

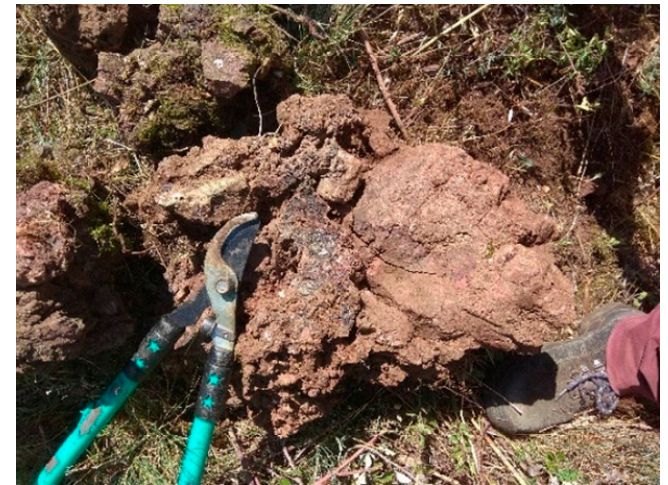

(b)

Figure 1. The samples studied were collected along the northern and north-west border of Serravuda top hill, Acri (Cosenza, Italy). Cemented blocks collected at the NW flanks of the Serravuda hill labelled SV 1 (a) and cemented blocks collected at the NW flanks of the Serravuda hill labelled C (b).

\subsection{Sample Preparation}

The samples analyzed in this study were collected in 2018 (SV samples) and 2019 (SE samples). A total of 25 samples were prepared for the mineralogical and chemical analyses. The samples include: (i) substrate rocks collected on the center of Serravuda top hill; (ii) blocks cemented by large glass (up to $80 \mathrm{~cm}$ ) consisting of fragments of heterogeneous rocks cemented by a vitreous material black in color collected on the NW side of Serravuda top hill; and (iii) glassy material prepared breaking up block (Figure 1a) and C (Figure 1b) and sieving the fragments into fractions of $>1000 \mu \mathrm{m}, 1000-500 \mu \mathrm{m}$, and 500-250 $\mu \mathrm{m}$.

The sampling and the choice of the material to analyze was carried out in order to obtain samples as representative as possible of the average mineralogical composition of the rocks and glasses.

\subsection{X-ray Powder Diffraction (XRPD)}

$X$-ray powder diffraction (XRPD) was used to identify the mineralogical composition of the 25 rock specimens (SV and SE samples) and the sieved glass samples. The analyses were performed at the Department of Geology and Environmental Science, James Madison University. X-ray patterns were collected at room temperature using a Malvern PANalytical Empyrean S3 diffractometer equipped with an $\mathrm{X}^{\prime}$ Celerator detector, and $\mathrm{CuK} \alpha$ radiation $(45 \mathrm{kV} / 40 \mathrm{~mA})$. The incident beam optical module Malvern PANalytical BraggBrentanoHD was used to improve the peak-to-background ratio and increase intensity in measured spectra. Analyses of the samples were carried out with spinner-mode analysis, with a $2 \theta$ scan range between $3^{\circ}$ and $70^{\circ}$, a step size of $0.02^{\circ} 2 \theta$, a divergence slit of $0.125^{\circ}$, and anti-scatter slits of $0.5^{\circ}$. The fitted peak width for collected data was about $0.01^{\circ} 2 \theta$. Quantitative mineralogical analyses were performed using PANalytical's HighScore Plus version 4.8 software [4]. Pure crystalline $\mathrm{Al}_{2} \mathrm{O}_{3}$ was chosen as an external standard and was analyzed under the same instrumental conditions as the samples.

\subsection{Scanning Electron Microscopy/Energy Dispersive X-ray Spectroscopy (SEM/EDS)}

Polished thin sections ( $\sim 30 \mathrm{~mm}$ thick) of sample 1-A were initially investigated with a petrographic microscope in plane-polarized and crossed-polarized light. The thin sections and vitrified rock fragments (size 1000-500 $\mu \mathrm{m}$ ) were studied using a Thermo Scientific Phenom XL G2 Desktop Scanning Electron Microscope (SEM) at the Department of Geology and Environmental Science, James Madison University.

A Leica EM ACE600 carbon coater was used to apply a sputtering carbon layer of $160 \AA$ A on all samples analyzed. Backscattered electron (BSE) images were collected using 
the Phenom XL and energy-dispersive spectroscopy (EDS) was used to determine the qualitative chemical composition of the minerals embedded in the vitrified samples. The images were collected in high vacuum at an accelerating voltage of $15 \mathrm{kV}$.

\section{Results}

Quantitative X-ray powder diffraction (XRPD) analyses on the studied materials are reported in Table 2 and in graphical form in Figure 2.

Table 2. Mineralogical composition of analyzed samples calculated via Rietveld method fitting the complete experimental X-ray powder diffraction (XRPD) patterns with calculated profiles and background. Crystalline and amorphous concentrations in $w t \%$, as determined by Rietveld analysis. Mineral abbreviations from Whitney and Evans [5]. Qz = quartz, Pl = plagioclase, Crs = cristobalite, Mul = mullite, $\mathrm{Hc}=$ hercinite; $\mathrm{Trd}=$ tridimite; $\mathrm{Sa}=$ sanidine; Ms = muscovite; Coe = coesite; Hem = hematite; Sil = sillimanite; $\mathrm{Bt}=$ biotite; $\mathrm{En}=$ enstatite; $\mathrm{Prh}=$ prehnite; $\mathrm{Crd}=$ cordierite; $\mathrm{Clc}=$ clinochlore; $\mathrm{Ol}=$ olivine; $\mathrm{Mag}=$ magnetite; $\mathrm{Mfr}=$ : magnesioferrite; Aug = augite; Ky = kyanite .

\begin{tabular}{|c|c|c|}
\hline Sample & Mineral Concentration (wt\%) & Amorphous Concentration (wt \%) \\
\hline \multicolumn{3}{|c|}{ Substrate rocks } \\
\hline SE 3 & Qz 12.3, Pl 10.2, Clc 6.5, Sa 3.3 & 67.7 \\
\hline SE 5 & Qz 16.1, Pl 9.7, Ms 0.5, Clc 0.1 & 73.7 \\
\hline SE 8 & Qz 11.3, Pl 7.3, Prh 6.2, Clc 0.1 & 75.2 \\
\hline SE 10 & Qz 5.3, Pl 5.6, Clc 0.7, Bt 0.1 & 75.2 \\
\hline \multicolumn{3}{|c|}{ Heated of Partially Vitrified Rock Fragments } \\
\hline SV 1-3P & Qz 50.9, Crs 5.7, Pl 1.2, Crd 0.2, Hr 0.1 & 41.8 \\
\hline SV 3-A & Qz 13.6, Ms 6.2, Clc 4.5 & 75.7 \\
\hline SV 4-C & Qz 26.8, Pl 9.9, Cdr 0.8 & 62.4 \\
\hline SV 5 & Hr $10.9, \mathrm{Ol} 2.2, \mathrm{Mul} 1.4$ & 82.2 \\
\hline SV 6 & Pl 18.8, Aug 3.5, Qz 2.4, Ky 0.4 & 75.0 \\
\hline SE 2 & Qz 20.4, Crs 3.6, Trd 0.6, Crd 0.4, Hr 0.3 & 74.7 \\
\hline SE 6 & Qz 25.1, Ms 0.5, Coe 1.0, Bt 0.2, Crs 0.1 & 71.0 \\
\hline SE 7 & Qz 7.5, Hr 3.8, Sil 2.6, Hem 1.3, Crs 0.3 & 84.4 \\
\hline SE 9 & Qz 5.3, Pl 5.6, Clc 4.6, En 1.7, B 0.3 & 82.3 \\
\hline SE 11 & Qz 1.1, Clc 1.1, Bt 0.5 & 97.3 \\
\hline SE 12 & Qz 1.1, Hr 0.4, Crs 0.2, Cdr 0.2 & 98.2 \\
\hline SE 13 & Qz 4.0, Crs 0.2 & 95.8 \\
\hline SE 14 & Clc 2.7, Bt 0.4, Hc 0.1 & 96.9 \\
\hline SE 15 & Qz 1.00, Bt 0.7, Clc 0.1 & 98.1 \\
\hline \multicolumn{3}{|c|}{ Vitreous Cements from Blocks SV1 and C } \\
\hline SV $1-2$ & Hc $18.8, \mathrm{Ol} 10.7, \mathrm{Pl} 6.2$, Qtz 0.8 & 63.5 \\
\hline SV $1-3 \mathrm{~V}$ & Pl 9.7, Qz 4.2, Crs 2.3, Mag 2.2 & 81.4 \\
\hline SV 1-4 & Pl 5.2, Qz 2.3, Ens 2.4, Bt 0.1 & 88.1 \\
\hline SV 1-A & Hr 12.1, Pl 9.3, Ol 7.5, Crd 2.2, Qz 1.8, Mag 1.2 & 65.9 \\
\hline SV 1-B & Qz 5.6, Pl 3.8, Crd 2.1, Hr 1.4, Crs 0.1 & 87.1 \\
\hline SV $4-\mathrm{V}$ & Pl 15.4, Qz 0.6, Crs 0.6, Mag 0.6, Mfr 0.6 & 82.2 \\
\hline
\end{tabular}

Quantitative mineralogical composition calculated via the Rietveld method on SE 3, SE 5, SE 8, and SE10 samples confirms field and thin section observations. The samples can be identified as quartz-plagioclase-rich granitoids. XRPD pattern of the SE 3 sample, a reddish fine grained granitoid collected on top of an elevation $50 \mathrm{~m} \mathrm{N-E}$ from the Serravuda hill, shows $3.3 \mathrm{wt} \%$ of sanidine. Sanidine is the high temperature form of K-feldspar and it can be found in metamorphic rocks formed at low pressure and high temperature. The occurrence of prehnite in sample SE 8 is consistent with observed whitish secondary veins, suggesting that SE 8 was subjected to secondary hydrothermal processes.

The effects of weathering in a Mediterranean climate on the mineralogy and microfabric of granitic and metamorphic rocks from the Sila Massif, Calabria, Southern Italy has been documented [6-9]. Medium-to-high-grade metamorphic and plutonic rocks were deeply weathered under the late Miocene (Sila Massif emerging time) to the present time $[6,10]$. The high content of amorphous in SE 3, SE 5, SE 8, SE 9, SE 10, SE 14, and 
SE 15 (Table 2) confirms that the samples were subjected to chemical decomposition due to weathering effects.

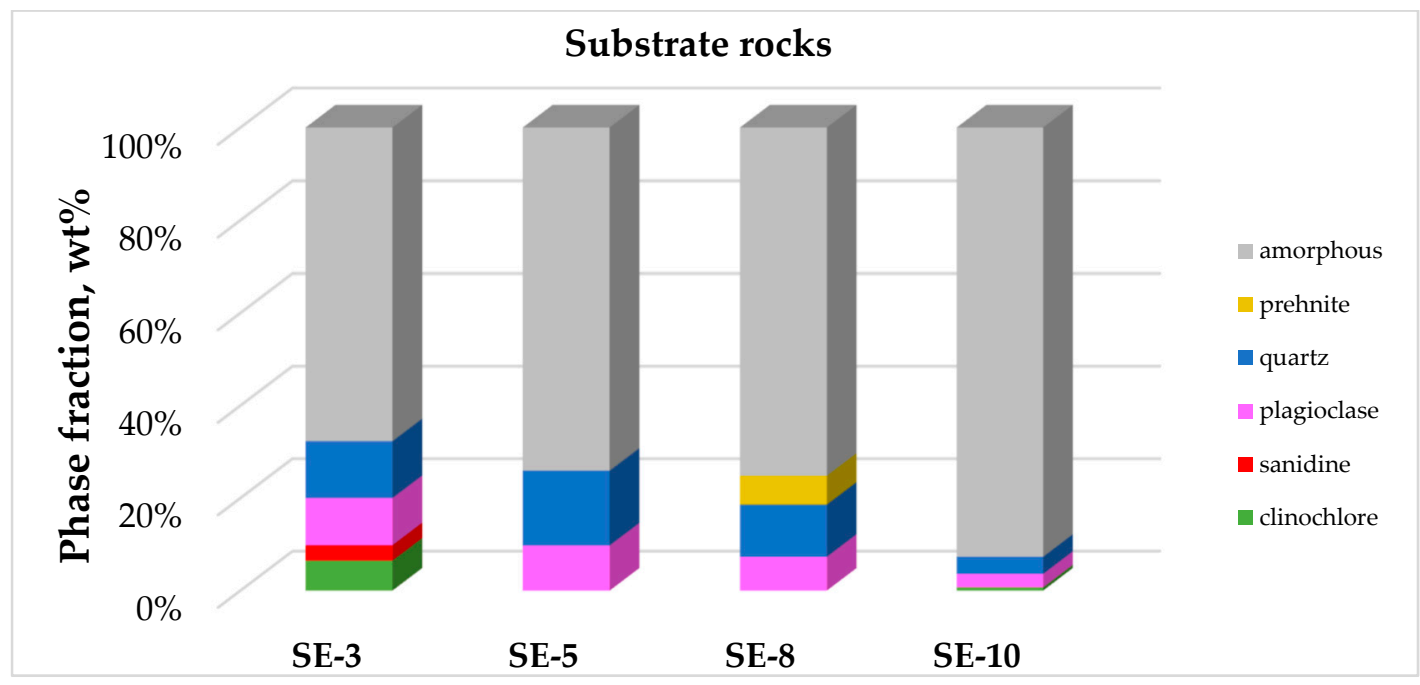

(a)

\section{Heated or partially vitrified rock fragments}

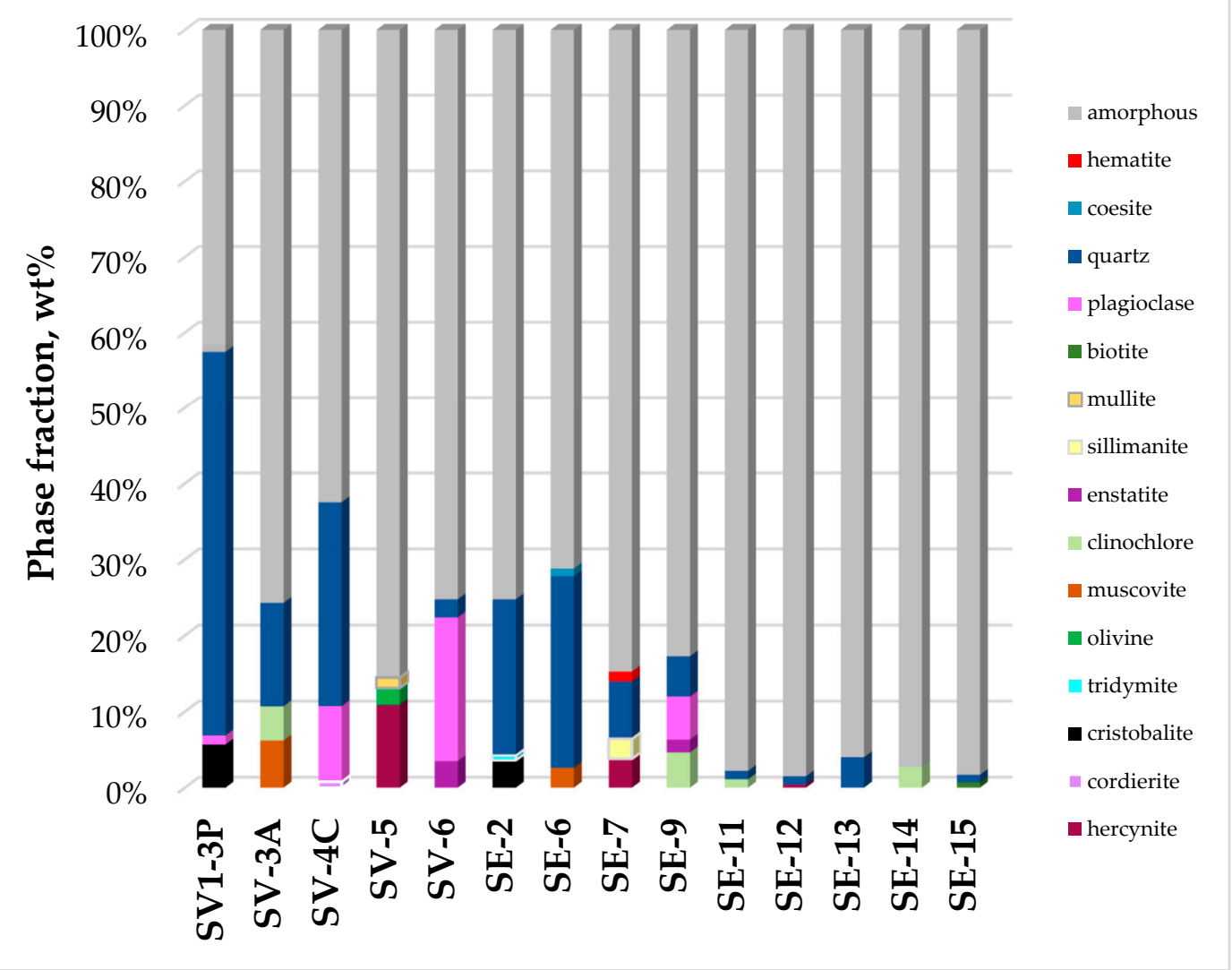

(b)

Figure 2. Cont. 


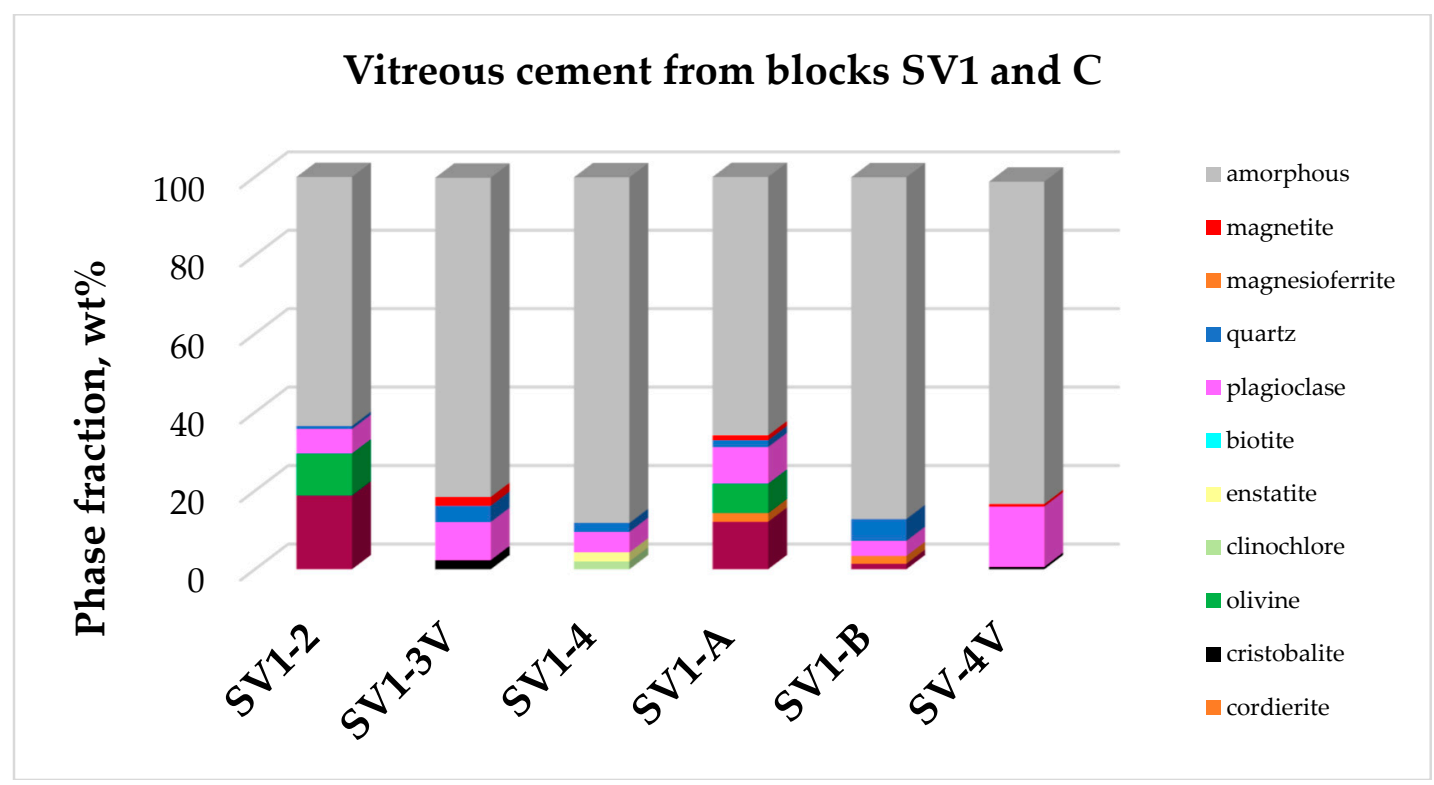

(c)

Figure 2. Quantitative mineralogy of the twenty five analyzed samples calculated via Rietveld method. (a) Relative abundances of main mineral phases $(>1 \%)$ in substrate rocks; (b) Relative abundances of main mineral phases ( $>1 \%)$ in heated or partially vitrified rock fragments; (c) Relative abundances of main mineral phases ( $>1 \%)$ in vitreous cement from blocks SV1 and C.

The mineralogical composition of heated or partially vitrified samples is heterogeneous (Table 2) owing to the effects of heating events, but it mostly recalls the parent rock composition (gneiss, granitoid, and amphibolite). SE 9, SE 14, and SE 15 were collected on the NE flank of the Serravuda hill and were identified as gneiss. XRPD quantitative analyses confirmed field and thin section identification of the samples as gneissic rocks. X-ray powder diffraction (XRPD) analyses showed cristobalite in SV 1-3P, SE 2. Hercynite and cordierite were observed in SV 1-3P, SV 4-C, SE 2, and SE 6. XRPD data suggest that a heating event introduced modifications of the mineralogy compared to the source substrate rocks.

Aluminosilicate minerals (sillimanite, mullite, and kyanite) were observed in SV 5, SE 6, and SE 7 patterns. Phyllosilicates (muscovite and clinochlore) were observed in SV 3-A. Olivine was observed in SV 5 pattern. In the XRPD pattern of SE 6, coesite was observed associated to cristobalite and quartz. Coesite in SE 6 and olivine in SE 5 can be residual phases from the parent material. Low intensity peaks of tridymite were observed in the SE 2 XRPD pattern.

$X$-ray powder diffraction data on the vitreous cementing materials noted the ubiquitous presence of plagioclase and Fe oxides (hercynite and magnetite) accompanied in some cases by quartz and cristobalite. Olivine was observed in SV 1-2 and SV 1-A. Enstatite was present in samples SV 1-4.

Low intensity peaks of cristobalite were observed in SV 1-3V, SV 1-B, and SV 4-V XRPD patterns. SV 1-A and SV 1-B XRPD patterns showed hercynite and cordierite as residual minerals. Magnetite was observed in SV 1-3V, SV 1-A, and SV 4-V XRPD patterns.

Scanning electron microscopy (SEM) with Energy dispersive X-ray spectroscopy (EDS) analysis in SV 1-A shows that hercynite, plagioclase, and quartz are widespread as remnant minerals from the source material (Figure 3a). These minerals are embedded in a vesicular silica rich, glassy matrix. Skeletal-dendritic crystals of plagioclase (Figure 3b) partially melted olivine (Figure 3c) and fractured quartz (Figure 3d) were observed via SEM in the glass fraction. The morphology of plagioclase suggests that the mineral was subjected to isothermal supercooling and constant rate cooling activity. 


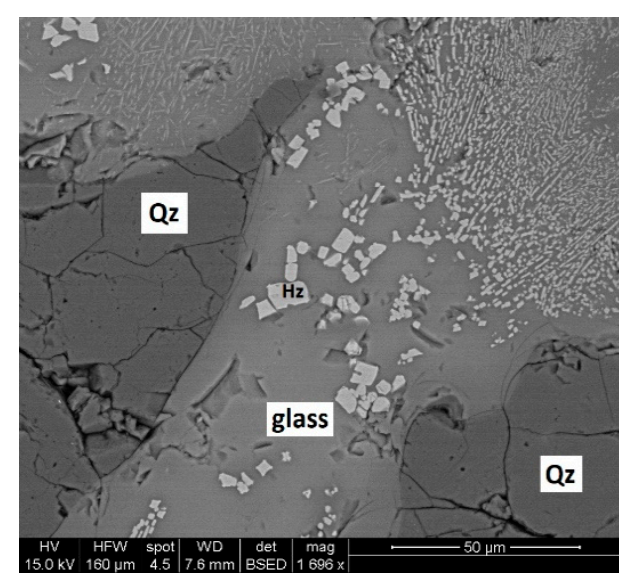

(a)

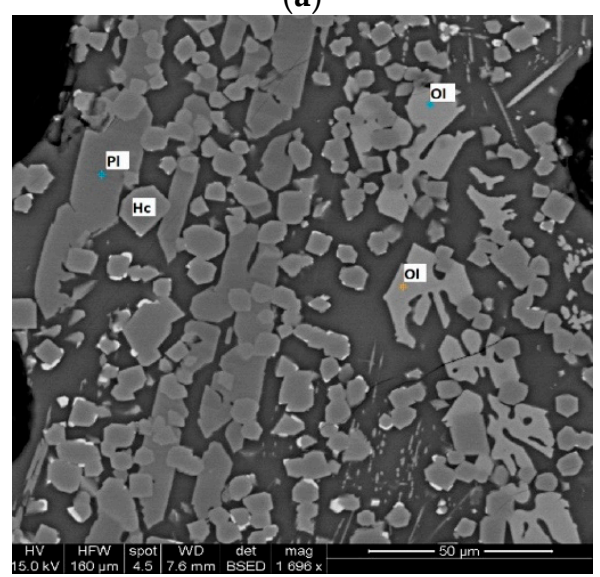

(c)

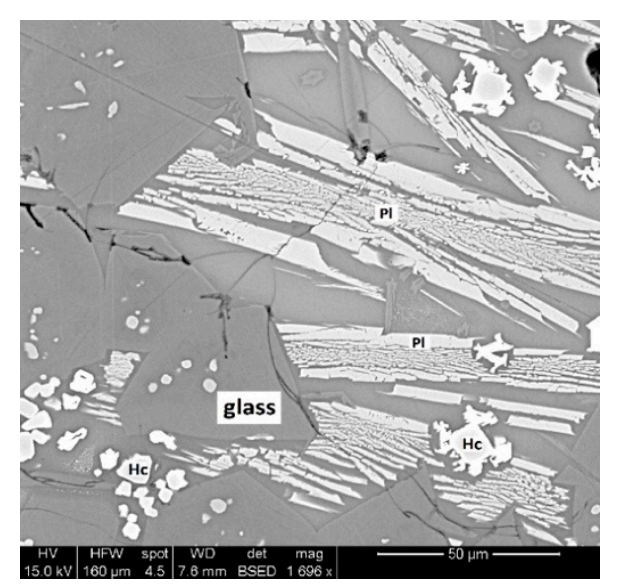

(b)

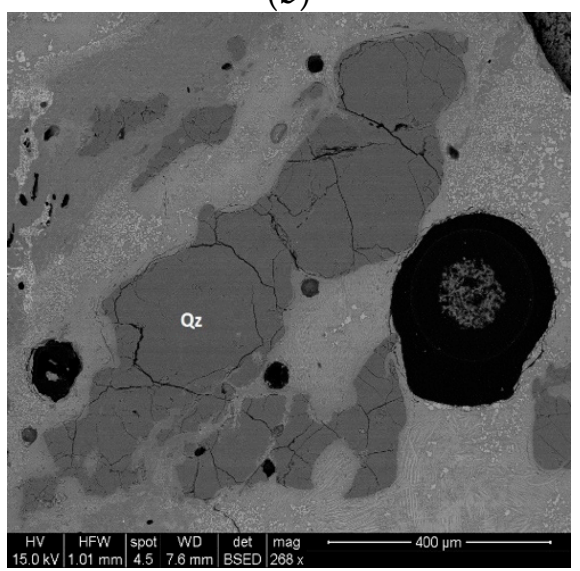

(d)

Figure 3. Backscattered scanning electron (BSE) images of sample SV 1-A. (a) hercynite and quartz crystals are widespread as remnant minerals from the source material; (b) skeletal-dendritic crystals of plagioclase in the glass fraction; (c) partially melted olivine; (d) fractured crystal of quartz.

The average chemical composition of plagioclase and olivine was determined by SEM-EDS (Table 3). The average composition of plagioclase is $\mathrm{Ab}_{69.63} \mathrm{An}_{11.94}$. The average composition of olivine is $\mathrm{Fo}_{36.82} \mathrm{Fa}_{60.51}$. The glass composition was determined by SEMEDS, as well. It is composed mainly of $\mathrm{SiO}_{2}, \mathrm{Al}_{2} \mathrm{O}_{3}$, and $\mathrm{FeO}$ (tot) in the analyzed areas (Table 4).

Table 3. Chemical data for plagioclase and olivine in Serravuda vitrified sample SV 1-A by scanning electron microscopy (SEM) with Energy dispersive X-ray spectroscopy (EDS) analysis. $n=$ number of data points.

\begin{tabular}{|c|c|c|c|c|c|c|}
\hline & Plagioclase & Olivine & & Plagioclase & & Olivine \\
\hline \multicolumn{3}{|c|}{$w t \%$} & & & \multicolumn{2}{|c|}{ apfu } \\
\hline$n$ & 6 & 4 & & & & \\
\hline $\mathrm{SiO}_{2}$ & 65.91 & 39.41 & Si & 3.13 & & 1.24 \\
\hline $\mathrm{TiO}_{2}$ & 5.33 & 2.22 & $\mathrm{Ti}$ & 0.19 & & 0.05 \\
\hline $\mathrm{Al}_{2} \mathrm{O}_{3}$ & 16.67 & 18.01 & Al & 0.93 & & 0.67 \\
\hline $\mathrm{FeO}$ (tot) & 4.11 & 20.22 & $\mathrm{Fe}^{3+}$ & 0.00 & & 0.00 \\
\hline $\mathrm{MgO}$ & 1.35 & 10.48 & $\mathrm{Fe}^{2+}$ & 0.16 & & 0.53 \\
\hline $\mathrm{CaO}$ & 1.17 & 0.23 & $\mathrm{Mg}$ & 0.10 & & 0.49 \\
\hline $\mathrm{Na}_{2} \mathrm{O}$ & 3.76 & 0.00 & $\mathrm{Ca}$ & 0.06 & & 0.01 \\
\hline $\mathrm{K}_{2} \mathrm{O}$ & 1.51 & 10.05 & $\mathrm{Na}$ & 0.35 & & 0.00 \\
\hline \multirow[t]{4}{*}{$\Sigma$} & 99.8 & 100.62 & $\mathbf{K}$ & 0.09 & & 0.40 \\
\hline & & & An & 11.94 & Fo & 47.66 \\
\hline & & & $\mathbf{A b}$ & 69.63 & $\mathbf{F a}$ & 51.59 \\
\hline & & & Or & 18.43 & Ca-O1 & 0.75 \\
\hline
\end{tabular}


Table 4. Chemical composition ( $w \mathrm{t} \%$ ) of glass in SV 1-A determined by scanning electron microscopy (SEM) with Energy dispersive X-ray spectroscopy (EDS) analysis. $n=$ number of data points.

\begin{tabular}{cc}
\hline Chemical Composition & Concentration (wt $\%)$ \\
\hline$n=6$ & \\
$\mathrm{SiO}_{\mathbf{2}}$ & 32.26 \\
$\mathrm{Al}_{\mathbf{2}} \mathbf{O}_{3}$ & 12.45 \\
$\mathbf{M g O}$ & 1.14 \\
$\mathbf{K}_{\mathbf{2}} \mathbf{O}$ & 1.22 \\
$\mathrm{CaO}$ & 1.33 \\
$\mathrm{TiO}_{\mathbf{2}}$ & 1.32 \\
$\mathbf{M n O}$ & 0.42 \\
$\mathbf{F e O}$ (total) & 34.11 \\
\hline
\end{tabular}

\section{Discussion}

The investigated materials include a set of samples of heated, partially melted rock fragments with vitreous cements. Samples show a complex mineralogical composition. Based on mineralogical and chemical results, all samples have been affected by the partial melting of parent rocks. The main lithologies identified are granitoid, amphibolite, and Fe rich-biotite gneiss (Table 1). The effects of a heating event can be ascribed to the chemical composition of the source material, adequate temperatures, and time to actually melt the rocks.

Mineral assemblages and their chemical compositions can contribute to elucidating the reactivity and the temperature range at which the heating event at Serravuda occurred. Several samples in the heated or partially vitrified samples and in the glass sample set show the major presence of quartz and cristobalite (Table 2). Cristobalite is a low-density quartz polymorph, occurring as a metastable crystal deposited from vapor within the pores of extrusive volcanic rocks [11,12]. Cristobalite can be used as indicator of a gassolid reaction occurring in fast cooling magma bodies [11]. Cristobalite high-temperature form ( $\beta$-cristobalite) is cubic and is stable between $1470{ }^{\circ} \mathrm{C}$ and $1728^{\circ} \mathrm{C}$ at a pressure of $1 \mathrm{~atm}$. This temperature equilibrium stability region applies only if the starting material is pure quartz [13]. Cristobalite can persist in metastability at much lower temperatures $\left(1100-1200^{\circ} \mathrm{C}\right)$ when in presence of K-feldspar and plagioclase, which act as a flux agent lowering the melting temperature of silica-rich materials. The transformation of the amorphous silica and quartz into cristobalite can occur during the melting process of silicic materials. If the liquid phase becomes supersaturated with silica as it cools, the excess can precipitate as cristobalite. Horwell et al. [12] suggest that prismatic and platy forms of cristobalite are found in pores of silicic rocks precipitated from a vapor phase. Vitreous cements from block SV 1 and C observed at SEM show diffuse vesicles and relicts of plagioclase (albite), quartz, and hercynite embedded in the glass. The vesicular texture suggests fast cooling occurred in the presence of a vapor (hydrous) phase. The XRPD pattern of SE 2 shows low intensity peaks of tridymite with cristobalite and quartz. Quartz and cristobalite are considered the only stable crystalline phases in $\mathrm{SiO}_{2}$ and $\mathrm{Al}_{2} \mathrm{O}_{3}$ rich-glasses.

Plagioclase crystals were observed to be suitable substrates for the initial deposition of impure cristobalite and tridymite [11]. Holmquist et al. [14] observed that tridymite is a binary incongruent melting phase and persists as metastable at low temperatures in the presence of plagioclase. Darling et al. [13] observed a diffusive loss of water from albite inclusions in cristobalite under isothermal, isochoric conditions resulted in an internal pressure decrease that promotes the metastable crystallization of cristobalite. Cristobalite forms before tridymite in the conversion of quartz at 890 to $900{ }^{\circ} \mathrm{C}$ and the presence of plagioclases and K-feldspar promote the conversion [15,16]. Mineral assemblage (quartz, tridymite, cristobalite, and plagioclase) in Serravuda heated and partially vitrified rocks and glasses and reflected temperatures in the range about $900-1100{ }^{\circ} \mathrm{C}$ in presence of hydrous gas, assuming thermodynamic equilibrium. 
The phase reactions that occurred during the heating event in starting materials rich in phyllosilicates are observed. Mullite, hercynite, cordierite, and olivine formed at relatively low temperature conditions $\left(900-1100{ }^{\circ} \mathrm{C}\right)$, in the presence of water vapor.

Mullite is the only chemically stable intermediate phase at atmospheric pressure in the $\mathrm{SiO}_{2}-\mathrm{Al}_{2} \mathrm{O}_{3}$ system. The rapid growth of mullite through a solution-precipitation process is promoted by the formation of a $\mathrm{SiO}_{2}$-rich liquid phase and the crystallization of cristobalite [17]. Mullite also forms at elevated temperatures as the final product of a series of reactions with phyllosilicates [18]. Ban et al. [18] observed that mullite crystallizes directly from amorphous phase rich in $\mathrm{SiO}_{2}$ and $\mathrm{Al}_{2} \mathrm{O}_{3}$ at around $1000{ }^{\circ} \mathrm{C}$. Water vapors could enhance the formation of mullite [19]. A little amount of mullite (1.4 wt $\%$ ) was shown in the sample SV 5 XRPD pattern and it can be ascribed to the reaction of quartz, cristobalite, and phyllosilicates that were present in the parent material (mica rich-gneiss).

In SV 5, hercynite and mullite were observed in the XRPD pattern. High amounts of hercynite were also observed in SV 1-2 and SV 1-A. The formation of hercynite is favored in the presence of $\mathrm{Al}_{2} \mathrm{O}_{3}$, hematite, and $\mathrm{H}_{2} \mathrm{O}$ under low oxygen conditions and slow cooling. The reactions could be cycled in two steps between $1200^{\circ} \mathrm{C}$ (reduction) and $1000{ }^{\circ} \mathrm{C}\left(\mathrm{H}_{2} \mathrm{O}\right.$ splitting) [20]. Li et al. [19] observed that the $\mathrm{Fe}_{2} \mathrm{O}_{3}$ obtained from the $\mathrm{Fe}_{3} \mathrm{O}_{4}$ reduction preferentially reacts with alumina in kaolinite to form hercynite. Meanwhile, the silica in kaolinite is transformed into a quartz solid solution and/or a cristobalite solid solution. With increasing heating temperature (above $1200^{\circ} \mathrm{C}$ ), Li et al. [19] observed that fayalite was formed by the reaction of surplus ferrous oxide with silica at a low temperature. Similarly, the hercynite observed in higher amounts in SV 1-2 and SV 1-A and olivine (fayalite) found in SV 1-A could crystallize from the separation reaction of iron, silica, and alumina in aluminosilicates and phyllosilicates in the parent rock.

Cordierite was observed in XRPD patterns of SE 2, SE 12, SV 1-3P, SV 4-C, SV 1-A, and SV 1-B. Regarding the formation of cordierite by a solid-state reaction, cordierite begins to form at $1100{ }^{\circ} \mathrm{C}$ between mullite, enstatite, and cristobalite, and reaches a peak at $1275^{\circ} \mathrm{C}[21,22]$. Porous cordierite was observed to crystallize in the presence of quartz at $1000{ }^{\circ} \mathrm{C}$ in air [23-25].

Pyrometamorphism refers to changes induced in rocks by high temperatures at low pressures caused by combustion [26,27]. Partial melting may lead to the formation of glassy rocks whose composition is close to that of the low- $\mathrm{P}_{\mathrm{H} 2 \mathrm{O}}$ eutectic in the system quartzalbite-K-feldspar, containing euhedral or subhedral grains of tridymite, cordierite, mullite, corundum, plagioclase, and spinel [27]. Combustion metamorphic (CM) rocks are products formed by the combustion of coal, gas, or other organic matter [26]. Grapes [23] observed that pyrometamorphosed quartzofelspathic rocks and their metamorphosed equivalents (phyllite, schist, gneiss) are characterized by the presence of tridymite, mullite, sillimanite, cordierite, orthopyroxene, clinopyroxene, sanidine, plagioclase, corundum, hercyniterich spinel, magnetite, ilmenite, and hematite. Mullite, cristobalite, tridymite, hematite, leucite, illite, kaolinite, sulfur, and pyrite were observed as newly formed combustion metamorphic products in metamorphic rocks of the Erin Formation in Trinidad associated with the combustion of lignite beds [24]. The maximum temperature of combustion reached in the Erin formation samples was $1100{ }^{\circ} \mathrm{C}$ [24]. Mineral assemblages observed in Serravuda partially vitrified and vitrified samples are consistent with pyrometamorphism processes. The residual phases (quartz, cristobalite, tridymite, mullite, hercynite, cordierite) embedded in the glass of vitrified samples from Serravuda suggest that the temperature did not exceed $\sim 100{ }^{\circ} \mathrm{C}$, at atmospheric conditions, in the presence of burning organic material (i.e., wood or coal), and assuming thermodynamic equilibrium.

\section{Prospective Origin of Serravuda Vitrified Rocks}

The Sila massif in northern Calabria (Southern Italy) is known for the presence of Bruttii (IV-I B.C.) and Roman (I B.C.-IV A.D.) settlements from the Middle Bronze until the Iron Age [25,28,29]. Protohistoric remains in the southern side of Serravuda hill indicating human activities were found in Serravuda by Bertolani [1]. 
Gualtieri [30] observed the rapid development of fortifications consisting of a number of wall circuits in different areas of Samnium, Lucania, and Bruttium territories in the later Iron Age (V and IV centuries B.C.). The author suggests that these fortifications could have a defensive function owing to a period of transformations and instability preceding the Romanization of Italy. Recent field observations at the location of the cemented gravelsized rock slabs (the top of Serravuda hill), the morphology of the structure formed by these vitrified cemented blocks (walls set in elliptical shape), an allochthonous derivation from most of the heated rock fragments, and mineralogical data suggest that Serravuda vitrified rocks are the result of anthropic activities and could represent remnants of ancient defensive architecture with timber-laced structures built with locally sourced rock slabs and inclusion within the wall-core of horizontal timbers disposed of longitudinally and transversally (Murus Gallicus type). Further investigations are required to confirm the age of Serravuda vitrified rocks.

Various vitrified forts, dated from the Late Bronze Age to the Early Medieval period, have been documented throughout western Europe [31,32]. Interpretations related to the building technique and their function through Bronze and Iron Ages suggest a certain degree of craft specialization and work planning. Many authors claimed that the vitrification was obtained through the combustion of timber interlacing within the walls and the fire was a deliberate act at the end of the fortification's life [31-38]. Further interpretations of the cause of the vitrification at these sites include ritual destruction (e.g., decommissioning of a site), destructive burning by enemies, incidental melting due to signal fires or lightning strikes [31,32,34,36-38].

The type of raw material used to build the fort walls, the morphology of firing structure, temperature, atmosphere, and the duration of firing influence microstructural and mineralogical changes. The heating rate (i.e., the rate of temperature development up to the maximum temperature) and the residence time (i.e., time of exposure to the maximum temperature) are the only variables that allow a distinction between different fortified structures.

The mineralogical composition of samples from Serravuda suggests that the vitrified materials were locally sourced granitoid, amphibolite, and gneiss. Residual minerals embedded in the glass matrix and identified via X-ray powder diffraction were used as geo-thermometers. The XRPD results from the partially vitrified samples suggest the firing temperature in the timber framework did not exceed $1100^{\circ} \mathrm{C}$. Mineral assemblage of partially vitrified rocks and glasses suggests that the fort walls were made of slabs derived from the local metamorphic rocks with the addition of granitic rocks to improve the strength and insulation of the fort walls.

Possible imprints of wooden poles or timbers were observed in Serravuda vitrified rocks where melting is more extensive (Figure 4).

Timber-lacing allows the heat transfer from the outside of the fortification into the stony wall core. The distribution and size of the timbers could be the predominant factor in determining the amount of combustible material in the timber-lined wall. Mineral phase assemblages found in Serravuda vitreous cements and heated rocks suggest that Serravuda vitrified rocks were partially melted in two steps: the first step reaction under reducing conditions and the second step reaction under oxidation conditions. Woodburning provides both oxidizing and reducing conditions. The reaction kinetics are mainly controlled by the amount of organic matter burning in the timber-laced wall. Stagnant air due to the poor ventilation inside the inner walls can be saturated with carbon and other products of decomposition from wood burning, which can consume oxygen, generating a low-oxygen environment. When the wood dries and burns, temperatures gradually rise to around $900-1000{ }^{\circ} \mathrm{C}$ in the wall core [32]. When the fuel is all consumed, the timber-laced wall is susceptible to the inward diffusion of air (i.e., $\mathrm{H}_{2} \mathrm{O}$ and $\mathrm{O}_{2}$ ) during the early phases of cooling, while the burning temperature is still high $\left(900-1000{ }^{\circ} \mathrm{C}\right)$. At temperatures above $900{ }^{\circ} \mathrm{C}$, the inner side of the fort walls starts to melt, forming a glassy crust in which residual and newly formed minerals are embedded. The mineral assemblage and amounts 
of crystal formed depend upon the parent material used to build the fort walls. The vitrified samples from Serravuda were formed through a combination of a solid state reaction and a thermal shock process involving quartz and phyllosilicates as reactants. Despite the oxidizing atmosphere of the firing, reducing conditions occurred when the wood was still burning, suggesting slow oxygen diffusion within the timber-laced walls. Mineral assemblages, such as hercynite, cordierite, and fayalitic olivine, were found embedded in the glass crystallized at temperatures above $900{ }^{\circ} \mathrm{C}$ due to the decomposition of Fe richphyllosilicates in low oxygen conditions. When all the fuel was consumed, temperatures were still above $900^{\circ} \mathrm{C}$ but, due to poor insulation, air flows into the walls generated oxidation conditions. Some aluminosilicate crystals (mullite) and the polymorph of quartz, such as tridymite and cristobalite, nucleated from the melted rocks, forming the vitrified walls during the cooling stage when the oxygen diffusion increased.

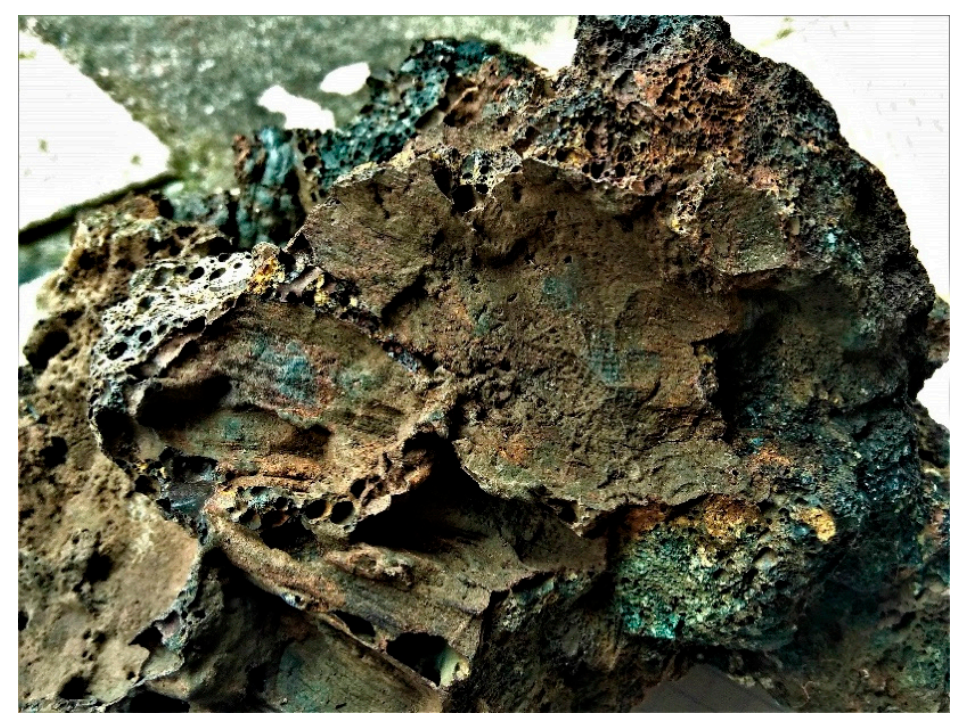

Figure 4. Block of vitrified rock with a potential wooden pole or timber imprint collected on the top hill of Serravuda.

Author Contributions: Conceptualization, C.E. and G.S.; Data curation, C.E., A.C. and G.S.; Investigation, C.E., A.C., F.L. and G.S.; Methodology, C.E.; Supervision, C.E.; Validation, C.E., A.C. and G.S.; Visualization, C.E.; Writing-Original draft, C.E. and G.S.; Writing-Review \& Editing, C.E., A.C., F.L. and G.S. All authors have read and agreed to the published version of the manuscript.

Funding: This research received no external funding.

Data Availability Statement: Not applicable.

Acknowledgments: Anonymous reviewers are kindly acknowledged for their thoughtful comments and suggestions that significantly improved the manuscript.

Conflicts of Interest: The authors declare no conflict of interest.

\section{References}

1. Bertolani, M. An enigmatic outcrop of vitrified rocks near Acri (Cosenza). Boll. Della Soc. Geol. Ital. 1972, 91, $683-692$.

2. Bertolani, M.; Foggia, F. La formazione kinzigitica della Sila Greca. Ital. J. Geosci. 1975, 94, 329-345.

3. Doglioni, C.; Flores, G. An Introduction to the Italian Geology; Il Salice: Potenza, Italy, 1994.

4. Degen, T.; Sadki, M.; Bron, E.; König, U.; Nénert, G. The Highscore suite. Powder Diffr. 2014, 29, S13-S18. [CrossRef]

5. Whitney, D.L.; Evans, B.W. Abbreviations for names of rock-forming minerals. Am. Mineral. 2010, 95, 185-187. [CrossRef]

6. Matano, F.; Di Nocera, S. Weathering patterns in the Sila Massif (Northern Calabria Italy). Ital. J. Quat. Sci. 1999, 12, 141-148.

7. Le Pera, E.; Critelli, S.; Sorriso-Valvo, M. Weathering of gneiss in Calabria, Southern Italy. CATENA 2001, 42, 1-15. [CrossRef]

8. Scarciglia, F.; Saporito, N.; La Russa, M.F.; Le Pera, E.; Macchione, M.; Puntillo, D.; Crisci, G.M.; Pezzino, A. Role of lichens in weathering of granodiorite in the Sila Uplands (Calabria, Southern Italy). Sediment. Geol. 2012, 280, 119-134. [CrossRef] 
9. Scarciglia, F.; Critelli, S.; Borrelli, L.; Coniglio, S.; Muto, F.; Perri, F. Weathering profiles in granitoid rocks of the Sila Massif Uplands, Calabria, Southern Italy: New insights into their formation processes and rates. Sediment. Geol. 2016, 336, 46-67. [CrossRef]

10. Biondino, D.; Borrelli, L.; Critelli, S.; Muto, F.; Gullà, G. The interplay of structural pathway and weathering intensity in forming mass-wasting processes in deeply weathered gneissic rocks (Sila Massif, Calabria, Italy). J. Maps 2018, 14, 242-256. [CrossRef]

11. Schipper, C.I.; Rickard, W.D.A.; Reddy, S.M.; Saxey, D.W.; Castro, J.M.; Fougerouse, D.; Quadir, Z.; Conway, C.; Prior, D.J.; Lilly, K. Volcanic $\mathrm{SiO}_{2}$-cristobalite: A natural product of chemical vapor deposition. Am. Mineral. 2020, 105, 510-524. [CrossRef]

12. Horwell, C.J.; Williamson, B.J.; Llewellin, E.W.; Damby, D.E.; Le Blond, J.S. The nature and formation of cristobalite at the Soufrière Hills Volcano, Montserrat: Implications for the petrology and stability of silicic lava domes. Bull. Volcanol. 2013, 75, 696. [CrossRef]

13. Darling, R.S.; Chou, I.-M.; Bodnar, R.J. An occurrence of metastable cristobalite in high-pressure garnet granulite. Science 1997, 276, 91-93. [CrossRef] [PubMed]

14. Holmquist, S.B. Conversion of quartz to tridymite. J. Am. Ceram. Soc. 1961, 44, 82-86. [CrossRef]

15. Cole, S.S. The conversion of quartz into cristobalite below $1000{ }^{\circ} \mathrm{C}$ and some properties of cristobalite formed. J. Am. Ceram. Soc. 1935, 18, 149-154. [CrossRef]

16. Dapiaggi, M.; Pagliari, L.; Pavese, A.; Sciascia, L.; Merli, M.; Francescon, F. The formation of silica high temperature polymorphs from quartz: Influence of grain size and mineralising agents. J. Eur. Ceram. Soc. 2015, 35, 4547-4555. [CrossRef]

17. Davis, R.F. Mullite. In Concise Encyclopedia of Advanced Ceramic Materials; Brook, R., Ed.; Pergamon: Oxford, UK, 1991; pp. 315-317.

18. Ban, T.; Okada, K. Cristallization of mullite and immiscibility in $\mathrm{SiO}_{2}-\mathrm{Al}_{2} \mathrm{O}_{3}$ system. In Advanced Materials '93; Mizutani, N., Akashi, K., Kimura, T., Ohno, S., Yoshimura, M., Maruyama, T., Saito, Y., Przybylski, K., Stringer, J., Kawamura, H., et al., Eds.; Elsevier: Amsterdam, The Netherlands, 1994; pp. 483-486.

19. Li, X.; Wang, H.; Zhou, Q.; Qi, T.; Liu, G.; Peng, Z.; Wang, Y. Reaction behavior of kaolinite with ferric oxide during reduction roasting. Trans. Nonferrous Met. Soc. China 2019, 29, 186-193. [CrossRef]

20. Minowa, S.; Yamada, M.; Kato, M. The study on the formation and reduction of hercynite $\left(\mathrm{FeAl}_{2} \mathrm{O}_{4}\right)$. Tetsu-to-Hagane 1965 , 51, 2309-2321. [CrossRef]

21. Sedmale, G.; Sperberga, I.; Sedmalis, U.; Valancius, Z. Formation of high-temperature crystalline phases in ceramic from illite clay and dolomite. J. Eur. Ceram. Soc. 2006, 26, 3351-3355. [CrossRef]

22. de Brito, I.P.; de Almeida, E.P.; de Araújo Neves, G.; de Lucena Lira, H.; Menezes, R.R.; da Silva, V.J.; de Lima Santana, L.N. Development of cordierite/mullite composites using industrial wastes. Int. J. Appl. Ceram. Technol. 2021, 18, 253-261. [CrossRef]

23. Grapes, R.H. (Ed.) Quartzofeldspathic Rocks. In Pyrometamorphism; Springer: Berlin/Heidelberg, Germany, 2006; pp. 41-113, ISBN 978-3-540-29454-2.

24. Baboolal, A.A.; Knight, J.; Wilson, B. Petrography and mineralogy of pyrometamorphic combustion metamorphic rocks associated with spontaneous oxidation of lignite seams of the Erin formation, Trinidad. J. S. Am. Earth Sci. 2018, 82, 181-192. [CrossRef]

25. Jung, R.; Pacciarelli, M.; Zach, B.; Klee, M.; Thanheiser, U. Punta di Zambrone (Calabria)—A bronze age harbour site. First preliminary report on the recent bronze age (2011-2012 campaigns). Archaeol. Austriaca 2015, 99, 53-110. [CrossRef]

26. Chen, B.; Wang, Y.; Franceschi, M.; Duan, X.; Li, K.; Yu, Y.; Wang, M.; Shi, Z. Petrography, mineralogy, and geochemistry of combustion metamorphic rocks in the Northeastern Ordos Basin, China: Implications for the origin of "white sandstone". Minerals 2020, 10, 1086. [CrossRef]

27. Butler, J.R. Pyrometamorphism. In Petrology. Encyclopedia of Earth Science; Springer: Boston, MA, USA, $1990 ;$ pp. $491-492$.

28. Ippolito, F. Before the Iron Age: The Oldest Settlements in the Hinterland of the Sibaritide (Calabria, Italy). Ph.D. Thesis, Rijksuniversiteit Groningen, Groningen, The Netherlands, 2016.

29. Sevink, J.; de Neef, W.; Vito, M.A.D.; Arienzo, I.; Attema, P.A.; van Loon, E.E.; Ullrich, B.; den Haan, M.; Ippolito, F.; Noorda, N. A multidisciplinary study of an exceptional prehistoric waste dump in the mountainous inland of Calabria (Italy): Implications for reconstructions of prehistoric land use and vegetation in Southern Italy. Holocene 2020, 30, 1310-1331. [CrossRef]

30. Gualtieri, M. Fortifications and settlement organization: An example from pre-roman Italy. World Archaeol. 1987, 19, 30-46. [CrossRef]

31. Berrocal-Rangel, L.; García-Giménez, R.; Ruano, L.; Vigil de la Villa, R. Vitrified walls in the iron age of Western Iberia: New research from an archaeometric perspective. Eur. J. Archaeol. 2019, 22, 185-209. [CrossRef]

32. McCloy, J.S.; Marcial, J.; Clarke, J.S.; Ahmadzadeh, M.; Wolff, J.A.; Vicenzi, E.P.; Bollinger, D.L.; Ogenhall, E.; Englund, M.; Pearce, C.I.; et al. Reproduction of melting behavior for vitrified hillforts based on amphibolite, granite, and basalt lithologies. Sci. Rep. 2021, 11, 1272. [CrossRef]

33. Youngblood, E.; Fredriksson, B.J.; Kraut, F.; Fredriksson, K. Celtic vitrified forts: Implications of a chemical-petrological study of glasses and source rocks. J. Archaeol. Sci. 1978, 5, 99-121. [CrossRef]

34. Ralston, I. The Yorkshire television vitrified wall experiment at East Tullos, city of Aberdeen District. In Proceedings of the Society of Antiquaries of Scotland; Society of Antiquaries of Scotland: Edinburgh, UK, 1987; Volume 116, pp. 17-40.

35. Friend, C.R.L.; Dye, J.; Fowler, M.B. New field and geochemical evidence from vitrified forts in South Morar and Moidart, NW Scotland: Further insight into melting and the process of vitrification. J. Archaeol. Sci. 2007, 34, 1685-1701. [CrossRef]

36. Wadsworth, F.B.; Heap, M.J.; Dingwell, D.B. Friendly fire: Engineering a fort wall in the iron age. J. Archaeol. Sci. 2016, 67, 7-13. [CrossRef] 
37. Wadsworth, F.B.; Heap, M.J.; Damby, D.E.; Hess, K.-U.; Najorka, J.; Vasseur, J.; Fahrner, D.; Dingwell, D.B. Local geology controlled the feasibility of vitrifying iron age buildings. Sci. Rep. 2017, 7, 40028. [CrossRef]

38. Lock, G.; Ralston, I. (Eds.) Hillforts: Britain, Ireland and the Nearer Continent: Papers from the Atlas of Hillforts of Britain and Ireland Conference, June 2017; Archaeopress Publishing Ltd.: Oxford, UK, 2019; ISBN 978-1-78969-227-3. 